\title{
SOCIAL BEHAVIOUR AND THE USE OF MEDICAL SERVICES
}

\author{
BY \\ J. A. SAVIN,* M.A., M.B., B.Ch.(Cantab.), M.R.C.P. (Lond.), D.I.H. \\ Registrar, Department of Dermatology, St. George's Hospital, London
}

Some patients seem to make a disproportionate amount of work for their doctors (Backett, Heady, and Evans, 1954; Brotherston and Chave, 1956; Forbes, Mutch, Smith, and Tulloch, 1967). It is hard to tell how much of this is due to increased morbidity and how much to variation in the threshold for seeking medical attention. To overcome this difficulty attempts have been made to gauge the need for each complaint of ill-health (Thorpe, 1965; Burns, 1965; Krass, 1965). That it is not easy for the doctor himself to do this without bias, is shown by the use in other studies of emotive words such as "unscrupulous", "irresponsible", and "selfish" to describe patients who consult frequently. Classifying diseases according to their severity is also difficult (Jacob, 1968).

The problem can be approached from a different angle by considering the use of medical services in relation to social behaviour. In a ship's company one measure of a man's behaviour is the frequency with which he is punished for offences against naval discipline. In this paper an attempt is made to relate this to the use of medical services over a period of 15 months.

\section{The Study}

All ratings who had served for the same period of 15 months aboard a naval frigate in the Far East were included in the study. The 98 ratings were grouped by the number of times they had been punished by the ship's captain during this period. The average number of "fresh complaints" of illhealth (defined as an attendance at the sick-bay with a complaint for which the rating was not at that time having treatment) was found for each group (Table). The difference between the average number of complaints made by offenders and non-offenders is statistically significant $\left(\chi^{2}=11 \cdot 4 ; P<0.001\right)$.

-Formerly Surgeon Lieutenant, Royal Navy.
TABLE

SICKNESS COMPLAINTS RELATED TO NUMBER OF OFFENCES

\begin{tabular}{|c|c|c|c|c|c|c|c|}
\hline No. of Offences & 0 & 1 & 2 & 3 & $4+$ & Total & $\begin{array}{l}\text { Offend- } \\
\text { ers Only }\end{array}$ \\
\hline No. of Ratings & 37 & 22 & 14 & 15 & 10 & 98 & 61 \\
\hline No. of Complaints & 99 & 82 & 59 & 85 & 61 & 386 & 287 \\
\hline $\begin{array}{l}\text { Average No. of } \\
\text { Complaints per } \\
\text { Rating }\end{array}$ & $2 \cdot 7$ & $3 \cdot 7$ & $4 \cdot 2$ & $5 \cdot 7$ & $6 \cdot 1$ & $3 \cdot 9$ & $4 \cdot 7$ \\
\hline
\end{tabular}

The 38 senior ratings on average had rather fewer "fresh complaints" $(3 \cdot 0)$ than did the sixty junior ratings $(4 \cdot 5)$. The dividing line is between able and leading seaman; this is the first promotion at which serious selection by merit occurs. In several civilian studies (Park and Kidd, 1961; Kasl and French, 1962) sickness has seemed to be inversely related to job-status. The difference between the average number of "fresh complaints" made by offenders and non-offenders is not significant when senior ratings are considered, but is significant for junior ratings $\left(\chi^{2}=5 \cdot 3 ; P<0.05\right)$.

The "fresh complaints" were divided into "venereal" and "non-venereal". The difference between the average number of "non-venereal" complaints made by offenders and non-offenders is significant $\left(\chi^{2}=7 \cdot 9 ; P<0.01\right)$. This difference is not significant for "venereal" complaints but the same trend can be seen (Figure, overleaf).

\section{Discussion}

A ship's company is ideal for a study of this sort. The men came from roughly the same social class, lived in the same environment, ate the same food, were equally separated from home influences, and had equal access to the resident doctor. The rules of behaviour were fairly simple and known to all. 


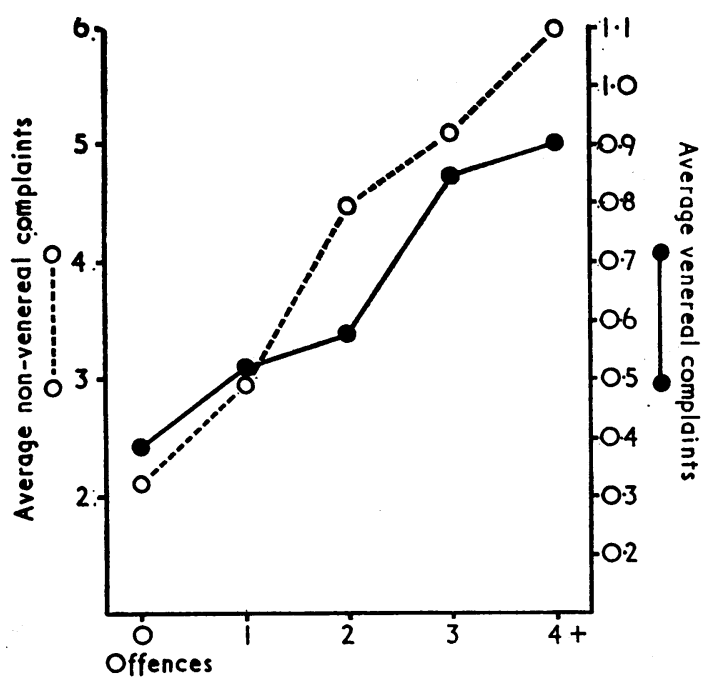

Frourk.-Number of offences related to venereal and non-venereal complaints.

The offences most commonly punished were leavebreaking, drunkenness, and visiting brothels. Few would have been punishable in civilian courts.

The term "fresh complaints" has been used rather than the "attendance rates" adopted in some other studies because the latter may be influenced by the doctor asking the patient to return for another visit (Stoeckle, Zola, and Davidson, 1963).

There is a difference between disease processes on the one hand and the use of medical services on the other (Mechanic and Volkart, 1961). In the case of the venereal diseases the offenders may be considered to have suffered from a real increase in ill-health and the link between the disease and the offence may have been a direct one (Savin, 1963) though this is usually thought not to be the case (Wittkower, 1949). The non-venereal complaints, however, were not linked in this way. Although frank malingering was probably uncommon, any real increase in ill-health must have been minor as all the ratings proved fit enough to serve for 15 months in trying physical conditions.

Civilian studies of delinquents, though not strictly comparable, have not shown a convincing association between delinquency and ill-health (Wootton, 1959). The rather high incidence of minor physical disorders found in delinquents (Eilenberg, 1961) may even be due to failure to use medical services (Scott, 1966).

One can only speculate about the link between offences and the use of medical services. Poor social adjustment may be associated with "clusters" of illness (Christenson, Kane, Wolff, and Hinkle, 1958) and, although rule-breaking may be one index of this, measurements of adjustment are rather unsatisfactory (Tindall, 1955; Fiedler, Dodge, Jones, and Hutchins, 1958).

Illness has been viewed as a special type of deviant behaviour perhaps resulting from social strains due to enforcement of group norms (Parsons, 1951a). It is one of a set of alternatives open to an individual, another being criminal behaviour, and may be one way of avoiding social responsibilities (Parsons, 1951b).

The type of promiscuity leading to venereal disease has been looked on as a way of trying to relieve acute psychological stress (Wittkower and Cowan, 1944) and indeed much illness behaviour may be the disguised seeking of help for primarily psychological problems (Stoeckle, Zola, and Davidson, 1964). People with the most bodily illnesses seem also to show the most disturbances of behaviour (Hinkle and Wolff, 1957). This increased susceptibility to all types of illness is related to personal factors; the vulnerable group adapt poorly to their environment and show an exaggerateds response to all minor forms of stress (Hinkle, 1961)

\section{SUMmaRY}

The ship's company of a frigate serving in the Far East formed a convenient closed community for a study of the use of medical services. "Fresh complaints" of ill-health were significantly associated with frequency of punishment for offences against naval discipline. This association was more marked for junior than for senior ratings who, on average, used the medical services less.

Venereal complaints seem to have been directly linked to the offences, and offenders suffered from a real increase in physical ill-health. Although a significant association with offences was found for non-venereal diseases the linkage here was not a direct one and any increase in physical ill-health was probably minor. Some factors which may be important in this association are discussed.

I should like to thank the Medical Director General of the Royal Navy for permission to publish this paper. I am also grateful to Dr B. Schwartz for his advice on the manuscript, and to Instructor Commander R. G. Emmons, R.N., and Dr W. C. Noble for the statistical analysis. 


\section{REFERENCES}

Backett, E. M., Heady, J. A., and Evans, J. C. G. (1954). Brit. med. J., 1, 109 (Studies of a general practice, II).

Brotherston, J. H. F., and Chave, S. P. W. (1956). Brit. J. prev. soc. Med., 10, 200 (General practice on a new housing estate).

BURNs, L. J. (1965). Brit. med. J., 2, 761 (General practice-at home, and abroad).

Christenson, W. N., Kane, F. D., Wolff, H. G., and HINKLE, L. E. (1958). Clin. Res., 6, 238 (Studies in human ecology: perceptions of life experiences as a determinant of the occurrence of illness).

EIlenberg, M. D. (1961). Brit. J. Crim., 2, 111 (Remand home boys, 1930-1955).

Fiedler, F. E., Dodge, J. S., Jones, R. E., and Hutchins, E. B. (1958). J. abnorm. soc. Psychol., 56, 345 (Interrelations among measures of personality adjustment in nonclinical populations).

Forbes, J. A., Мutch, L. M. M., SMITH, G. T., and Tulloch, A. J. (1967). Brit. med. J., 3, 856 (Study of the demand for urgent treatment in general practice).

HinkLe, L. E. (1961). Psychosom. Med., 23, 289 (Ecological observations of the relation of physical illness, mental illness, and the social environment).

- and Wolff, H. G. (1957). Arch. intern. Med., 99, 442 (The nature of man's adaptation to his total environment and the relation of this to illness).

JACOB, A. (1968). J. roy. Coll. gen. Practit., 15, 40 (Quantitative diagnosis in an "artificial practice").

KaSL, S. V., and French, J. R. P. (1962). J. soc. Issues, 18, No. 3, p. 67 (The effects of occupational status on physical and mental health).
Krass, I. M. (1965). J. roy. Coll. gen. Practit., 10, 124 (Is there abuse in general practice?).

Mechanic, D., and Volkart, E. H. (1961). Amer. sociol. Rev., 26, 51 (Stress, illness behaviour, and the sick role).

PARK, A. T., and KIDD, C. W. (1961). Brit. J. prev. soc. Med., 15, 79 (Sick leave experience of civil servants in the government of Northern Ireland during 1958).

Parsons, T. (1951a). Amer. J. Orthopsychiat., 21, 452 (Illness and the role of the physician: a sociological perspective).

(1951b). "The Social System", p. 431. Free Press, Glencoe, U.S.A.

SAVIN, J. A. (1963). J. roy. nav. med. Serv., 49, 203 (The rhythm of venereal infection in a ship's company).

Scotr, P. D. (1966). Hosp. Med., 1, 219 (Medical aspects of delinquency).

Stoeckle, J. D., Zola, I. K., and Davioson, G. E. (1963). J. chron. Dis., 16, 975 (On going to see the doctor, the contributions of the patient to the decision to seek medical aid).

(1964). Ibid., 17, 959 (The quantity and

significance of psychological distress in medical patients).

THORPE, D. (1965). Practitioner, 194, 534 (Analysis of calls on a doctor's time in general practice).

Tindall, R. H. (1955). Educ. psychol. Measmt, 15, 152 (Relationships among indices of adjustment status).

WITTKower, E. D. (1949). In "Modern Practice in Psychological Medicine-1949", ed. J. R. Rees, p. 112. Butterworth, London.

( and Cowan, J. (1944). Psychosom. Med., 6, 287 (Some psychological aspects of sexual promiscuity).

Wootron, B. (1959). "Social Science and Social Pathology". Allen and Unwin, London. 